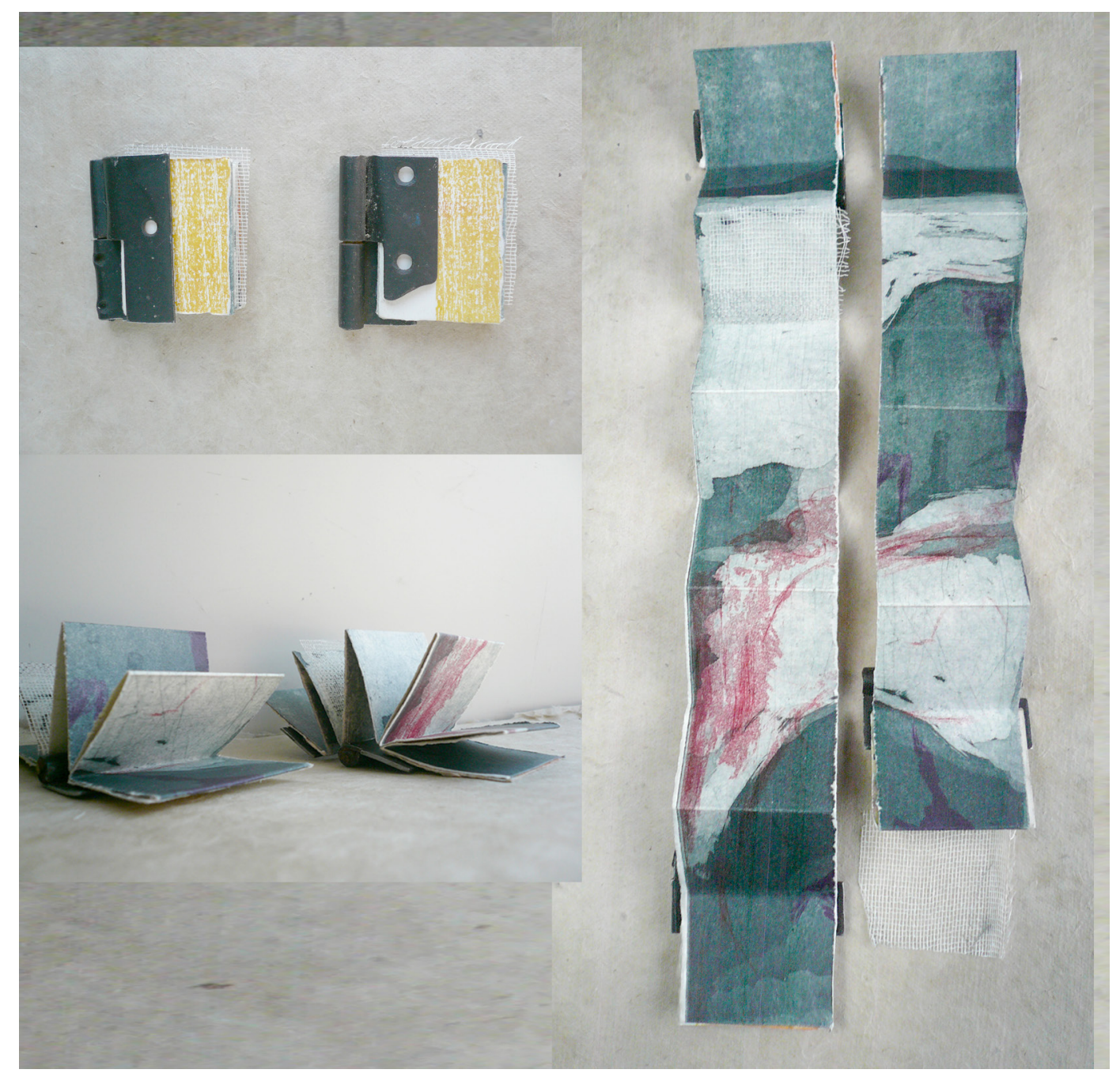

\title{
Contraventanas (fragmentos I-II)
}

\section{Reflexión}

Como elemento de transición entre interior y exterior, la ventana fue durante un tiempo una forma de conectar con el contexto. Mirar por la ventana complementaba el relato de los acontecimientos, una crónica construida desde una visión incrédula, fragmentada e interpretativa. El libro, como la ventana, se abre para rescatar fragmentos que, unidos, dejan entrever el paisaje deshabitado de un pueblo abandonado en otro tiempo.

\section{Autora}

Eva Mayo

Facultad de Bellas Artes. Universidad del País Vasco UPV/EHU.

Arteterapia: papeles de arteterapia y educación artística para la integración social.

Monográfico: Las miradas del arte y el arteterapia en tiempos de la Covid19. ISSN-e: 1988-8309 https://dx.doi.org/10.5209/arte.75940 